Kaygl, 19(1)/2020: 25-46. Araştırma Makalesi | Research Article

Makale Geliş | Received: 20.11.2019

Makale Kabul | Accepted: 20.01.2020

Yayın Tarihi | Publication Date: 25.03.2020

DOI: 10.20981/kaygi.698748

\author{
İlker ALTUNBAŞAK \\ Dr. Öğr. Üyesi | Assist. Prof. Dr. \\ ORCID: 0000-0002-0383-7362 \\ İlkeraltunbasak61@gmail.com
}

\title{
Felsefi Danışmanlık İçin Yeni Bir Kavram: Bunalım
}

\section{Öz}

Felsefi danışmanlık, psikolojik danışmanlığa alternatif bir danışmanlık türü olduğu iddiasını taşır. Bu iddia felsefi danışmanlığa alternatifi olduğu psikolojik danışmanlıktan farkının ne olduğu konusunu açık kılma ödevi yükler. Felsefi danışmanlar, söz konusu farkın danışanın sıkıntı ve sorunlarının hangi boyutta ele alındığında yattığını ileri sürerler. Felsefi danışmanlara göre sıkıntı ve sorunların kaynağı her zaman bireyin duygu durumları değildir. Bir kısım sıkıntı ve sorunların nedeni, bireyin inançları, düşünce kalıpları, önyargıları, hayatı kavrayış şekli, kısaca, çerçeve bir kavram olarak, onun dünya-hayat görüşüdür. Buna bağlı olarak da felsefi danışmanlıkta sıkıntı ve sorunlar kavramsal boyutta ele alınır; bir başka deyişle, danışanın sıkıntı ve sorunlarının nedeni olabilecek muhtemel duygu durumlarından uzak durulur. Dolayısıyla literatürde geçen sıkıntı ve sorun kavramları psikolojik yükler taşımaz. Peki, felsefi danışmanlık için, sıkıntı ve sorun kavramlarının yanında yine psikolojik yüklerden uzak yeni bir kavram belirlenebilir mi? Calışma soruya olumlu cevap verdiği ve literatüre bu konuda yeni bir kavram kazandıracağı iddiasını taşıyor. Batı dillerinde kullanılan ve Türkçeye "kriz" olarak geçen kelime anlamında bunalım, Nermi Uygur'un felsefi söyleminde yer aldığı haliyle felsefi danışmanlık için yeni bir çalışma alanı olabilir. $\mathrm{Bu}$ aynı zamanda kendini psikolojik danışmanlıktan ayırt etme ve kuramsal alt yapısını kurma çalışmalarında felsefi danışmanlığa önemli katkılar sağlayacaktır.

Anahtar Kelimeler: Felsefi Danışmanlık, Sıkıntı, Sorun, Bunalım, Nermi Uygur.

\section{A New Concept for Philosophical Counseling: Crisis}

\begin{abstract}
Philosophical counseling claims to be an alternative counseling type to psychological counseling. This claim imposes on the philosophical counseling a task of clarifying its difference from psychological counseling, to which it is alternative. Philosophical counselors argue that the main difference lies in the extent to which the counselee's predicaments and problems are addressed. According to philosophical counselors, the source of predicaments and problems is not always the individual's emotional states. The reasons for some predicaments and problems are the individual's thought patterns, prejudices, understanding of life, in short, his world-life view as a frame concept. Accordingly, the predicaments and problems are dealt with in philosophical counseling in the conceptual dimension; in other words, predicaments and problems caused by the counselee's emotional states are avoided. Therefore, the concepts of predicaments and problems taken place in the literature do not bear psychological burdens. For philosophical counseling, can a new concept that is far from psychological factors besides predicaments and problems be determined? The study asserts that it answers the question positively and will bring a new concept to the literature. The word "crisis" used in Western languages and referred to as "kriz" in Turkish can be a new concept for philosophical counseling as it is included in the philosophical discourse of Nermi Uygur. As well as this makes important contributions to philosophical counseling in differentiating itself from psychological counseling and establishing its theoretical infrastructure.
\end{abstract}

Keywords: Philosophical Counseling, Predicaments, Problems, Crisis, Nermi Uygur. 


\section{Giriş}

Modern felsefi danışmanlık uygulamaları ilk kez Almanya'da 1981 yılında Gerd B. Achenbach tarafindan başlatılmıştır. Bu yeni danışmanlık pratiğinin temel kalkış noktası bireyin her günkü hayatında karşılaştığı sıkıntı/sorunlarla ${ }^{1}$ başa çıkmasında, felsefece düşünmenin/felsefe yapmanın ona yardımı olacağı düşüncesidir (Achenbach 1995; Schuster 1999; Raabe 2000). Çünkü felsefi danışmanlara göre, sıkıntı ve sorunlarımızın altında yatan nedenler her zaman bireyin duygu durumlarından kaynaklanmaz. Bizim günlük hayata ait sıkıntı/sorunlarımızın bir bölümünün kaynağı sahip olduğumuz inançlar, değerler, varsayımlar, önyargılarımız, düşünce kalıplarımız, anlam yakıştırmalarımız, değer atfetmelerimiz gibi hayata dair kavrayışlarımızdır. Fakat birçok insan bir takım sorunlarının kaynağının bunlarla olan ilişkisinin farkında değildir.

İşte bir felsefi danışmanlık uygulamasında hayata geçen "felsefe yapma" sürecinde felsefi danışman ve danışan, bu kanıksanmış, sanki öyle olması gerekiyormuş gibi görünen kabulleri günlük yaşam ve deneyimlerle ilişkilendirip, böylece de danışanın kendisi ve içinde bulunduğu durumu anlamasını sağlayacak düşünce ortamını oluştururlar (Lahav 1994, 1996a, 2001; Prins-Bakker 1995; Schefczyk 1995; Mijuskovic 1995; Tuedio 1998; Norman 1995). Felsefi danışmanlar için sorunlarımız, aslında hayatın bize sorduğu felsefi sorulardır (Tillmans 2005:2) Böyle olunca da kişisel sorunlarımızın temelinde yatan da bizim bu sorulara verdiğimiz cevaplar olur. Bir bakıma cevaplarımız bizim hayat felsefemizin dışa yansımasıdır ki bu felsefi danışmanlık pratiğinde ele alınan, felsefi danışmalık literatüründeki terimleriyle, danışanın mevcut felsefi anlaması veya alışılmış anlamadır (Lahav 1995, 1996a). Kate Mehuron (2009), felsefe için "hayatla kurulan bir diyalog" der. Sorunlarımız hayatın bize sorduğu felsefi sorular olunca, onlarla yüzleşme anlarında hayatla diyaloğumuz bir anlamda hayatla felsefe yapmadır. Alışılmış anlama veya mevcut felsefi anlamamızla yaptığımız felsefeyle bazen sorunların üstesinden geldiğimiz olur. Fakat sorunların

${ }^{1}$ Metin boyunca sıkıntı/sorun kelime çiftiyle çok sık karşılaşacaksınız. Stkıntı kelimesi İngilizce predicament ve sorun kelimesi de problem kelimesine karşılık olarak kullanılmıştır. 
devam ettiği, büyüdüğü durumlarda bir danışmana ihtiyaç duyulur. Eğer bu bir felsefi danışman ise, yapılan, danışanın sorunlarına neden olduğu düşünülen yanlarıyla alışılmış anlamanın yerini, yine bir felsefi danışmanlık terimiyle ifade edilecek olursa yeni felsefi anlamanın almasıdır. Örneğin, çocuk sahibi olmak istememek (geçmişte yaşanan bir travma veya duygu durumlarından kaynaklanan nedenler dışında) bekar bir insan için sadece bir seçimdir ve sorun olarak düşünülmez ta ki bu kişi evlenmeye karar verene kadar. $\mathrm{O}$ andan itibaren artık çocuk isteyen bir eş adayının varlığı ile bu sorun çıkaran bir kabul olup tartışmaya açılır. Çocuk, evlilik, anne veya baba olmak gibi kavramlar, tıpkı felsefenin kavramlarla hesaplaşmasında olduğu gibi: Evlilik nedir? Çocuk sahibi olmak nedir? Anne veya baba olmak nedir? tarzında sorularla, bir bakıma bu kavramların anlamını soran hesaplaşma başlar. Danışan bu veya benzeri sorular etrafında yapılan felsefe sonucunda kendi alışılmış anlamasında çocuk sahibi olmakla ilgili bazı önyargıları, kalıpları fark eder, farklı düşünceler geliştirip, yeni felsefi anlamaya geçer ki bu kısa vadede söz konusu sorunun çözümü ve felsefenin bilgeliğe yolculuğuna ilk adımdır.

Felsefi danışmanlık, ilk kez uygulanmaya başlandığı günlerden itibaren yeni bir danışmanlık pratiği olma savıyla felsefi danışmanlar tarafından psikolojik danışmanlığa alternatif bir danışmanlık türü olarak görülmektedir (Schuster 1999). Fakat psikolojik danışmanlığa alternatif olma savı, felsefi danışmanların cevaplaması gereken bir soruyu da beraberinde getirir: Felsefi danışmanlığın alternatifi olduğu psikolojik danışmanlıktan farkı nedir? Bu soru felsefi danışmanları bir hayli uğraştırmaktadır. Konuyla ilgi literatürde detaylı bir tartışmayı takip etmek mümkün. Psikolojik danışmanlıktan olan farkların belirlenmesi, felsefi danışmanlığın kuramsal ve kavramsal çerçevesinin çizilmesi ve hatta meşruiyeti için de hayati öneme sahiptir (Amir 2004). Felsefi danışmanlar alanın psikolojik danışmanlıktan önemli farklarını sıralarken, bu yeni danışmanlık pratiğinin bizatihi "felsefi”" olması, danışmanlık sürecinde danışman ve danışanın eşit şartlarda, hasta-terapist ilişkisinden uzak felsefe yapmaları ve danışman otonomisi olarak ileri sürseler de (Achenbach 1984; Schuster 1999; Jongsma 1995; Veening 1994; Raabe, 2002a; Morstein 1987), aynı şartların bazı psikolojik 
danışmanlık türleri için de geçerli olması farkı belirlemede yeterli olmamaktadır. Sonuçta her iki danışmanlık türü de danışan sıkıntı/sorunları üzerine yoğunlaşır. İşte tam da bu noktada, felsefi danışmanlar iki danışmanlık türü arasındaki farkı belirgin hale getiren bir özelliği vurgular. Her iki danışmanlık tarzı da sıkıntı/sorunları ele alır ama felsefi danışmanlara göre, sıkıntı/sorunların ele alındığı boyut (Lahav 1995 : 13) veya kişi kavrayışı ve danışmanlıkta kişinin hangi boyutta ele alındığı konusu farkı belirler. Blass, Lahav'ın boyut konusu dediği yerde 'sinema perdesi' örneğini verir (Blass 1996a: 280). Kişiyi psikolojik bir perdeye yansıtırsak, onu ruhsal olaylar ağ içinde görürken, felsefi bir perdede aynı kişi kavramsal bağlantılar ve düşünceler ağı içinde görülür. Hoogendijk de Lahav ve Blass'in bu belirlemesine paralel olarak, sorunların farklı bakış açılarından farklı görünebileceğini savunur. Sorunlara teolojik, tıbbi veya psikoterapötik perspektiflerden bakınca, sorunlu insanlar bazen günahkâr, bazen hasta ve bazen de normal dışı görünebilir (Schuster 1999:53). Felsefi danışmanlık için ise, sorunlar, hayatın felsefi yorumunun odağındadır. Felsefi danışmanlığın, danışanın psikolojik durumuyla ilişkilendirilebilecek sorunlarıyla değil de, onun kendi felsefi anlaması, alışılmış anlama ve yaşamla ilgili kavramlaştırmaları ve değer atfetmelerinden kaynaklanan sıkıntı/sorunlarla ilgilendiği meselesi en açık halini Schefczyk'in belirlemesinde alır. Schefczyk (1995) kişinin yaşamını şekillendiren kavrayış şekillerini ve anlayışları betimlemek için Freud'un 'içgüdüsel dalgalanmalar' (instinctive vicissitude) kavramından esinlenerek kullandığı 'kavramsal dalgalanmalar' (conceptual vicissitude) kavramı (s.79) psikolojik danışmanlık ve felsefi danışmanlığın hareket noktalarını açık olarak ayırt etmesi açısından önemlidir. Freud içgüdüsel dalgalanmalar kavrayışını bireyin yaşamını şekillendiren psikolojik güçleri betimlemek için kullanmıştır. Kavramsal dalgalanmalar ise bireyin yaşamla ilgili olarak sahip olduğu kavrayışlarla ilişkilidir.

Peki, felsefi danışmanlığın "kavramsal dalgalanmalar" kaynaklı sıkıntı/sorunlara yaklaşım tarzı nedir? Felsefi danışmanlık bağlamında felsefe yapmak, danışanın yaşamdünyasının eleştirel bir biçimde sorgulanmasıdır. Danışman ile danışan arasında yapılan felsefenin içeriğini bütün yönleriyle danışanın yaşam-dünyası oluşturur. Bu felsefe 
yapma sürecinde danışan açısından hayata geçen felsefi kendini-soruşturma (Lahav1995,1996a) (philosophical self-investigation) sonucunda, danışanın, sıkıntı/sorunlarına kaynaklık ettiği düşünülen - ki bunlar farklı felsefi danışmanlarda farklı kavramlarla ifade edilir - dünyagörüşü (Lahav 1995), sistem/ilkeler (Mijuskovic 1995), yaşam soruları (Prins-Bakker 1995), yaşam ilkeleri (Uygur 2006) veya hayatı yönlendiren kavrayışlarının (Tuedio 1998) danışanın yaşam deneyimlerinde ortaya çıkan ve somut etkilere sebep olan yönleri deşilir. Su üstüne çıkarılmak istenen ve eleştirel olarak sorgulanan, danışanın hayatı kavrayışı, anlam dünyası, anlamlandırmaları, değerlendirmeleri, düşünce kalıpları, varsayımları veya önyargılarıdır. Yukarıda belirtilen kavramlar (dünyagörüşü, yaşam ilkeleri, sistem/ilkeler, yaşam soruları vd.) etrafında gerçekleşen felsefi kendini-soruşturma veya felsefe yapma sürecinde danışan, danışmanın yardımıyla, onun sunduğu felsefi düşünme araçları ile kendini sorgular. Felsefe yapma veya felsefi kendini-soruşturmanın amacı, danışanın bu soruşturma sonucunda yeni felsefi kendini-anlama (Lahav 1995) (philosophical self-understanding) ve kendi hakkındaki bilgiye (Jopling 1996) (selfknowledge) ulaşmasıdır. Danışanda, alışılmış anlamanın yerini yeni felsefi kendinianlama bırakması ve danışanın kendi hakkındaki bilgiye de sahip olur hale gelmesiyle sıkıntı/sorunların nedenleri de açık hale gelir.

Felsefi danışmanlık için, kavramsal dalgalanmalar boyutunda ele alınan sıkıntı(predicament)/sorunların(problem) yanısıra yine psikolojik yüklerden uzak başka bir özgün kavram olamaz mı? Bu çalışma felsefi danışmanlığa bu yeni özgün kavramı kazandırma iddiasını taşıyor: bunalım ve bu kavram için esinlenilen felsefeci de Nermi Uygur. Bu amaçla, Uygur'un felsefi söyleminde bunalım kavramı ele alınıp, felsefi danışmanlıkla ilişkilendirildi ve görüldü ki Nermi Uygur'un felsefi söylemi için de çok önemli olan bunalım kavramı, onun söyleminde yer aldığ 1 biçimiyle felsefi danışmanlıkta kullanılan sıkıntı/sorun kavramlarıyla birlikte felsefi danışmanlık uygulamalarında yer alabilir.

Nermi Uygur'a göre bunalım, insanın dışında, somut, ondan ayrı, örneğin genel geçer bir tanımı yapılabilecek bir nesne, bir inceleme konusu değildir. Bunalım insanla 
vardır, insan varsa bunalım vardır. Bunalım insanın bir parçasıdır. Dolayısıyla bunalım özneldir. Herkes kendi bunalımını yaşar, onu yine kendince sözcüklere döker. Uygur da kendi bunalımını Bunalımdan Yaşama Kültürü adlı eserinde dile getirir. Bu kitap bize, Uygur'un deyimiyle "yaşamın öbür adını, bunalımı" anlatır (Uygur 2012: 23). Bir "bunalımlar kitabı", "bitmeyen bunalımlar kitabı” olan bu yapıt, Betül Çotuksöken'e göre (Çotuksöken, 2001: 294), "bunalımın serüvenini dile getiren, bunalım üzerine bir kitaptır. ${ }^{2}$ Ekrem Işın, kriz tanımlarında her kuşağın merkeze din, siyaset, ekonomi, kültür gibi farklı hareket noktaları aldığını, “Uygur'un ise bu kitapta 'insan' merkezli bir krize, umut 1şığı yaktığını” ileri sürer (Işın 2010: 93). İsmail Ertürk’e göre ise filozof, dünyada az rastlanır bu kitabında, "bunalım üzerine kendi yaşamından yola çıkarak düşündüklerini” dile getirir (Ertürk 2010: 84). Güven Turan, Uygur'un, yaşamının "çok zor, bunalımlı bir dönemini anlatan kitabın, bir yanıyla ciddi bir varoluşçu felsefe üzerine kurulu olduğunu" ileri sürer (Turan 2011: 8). "Felsefe anlayışını, felsefenin bir kavram çalışması olduğu yönünde” (Çotuksöken 1995: 36) belirleyen Nermi Uygur'un tüm felsefi söyleminin 'dürtüsü' olan bunalım kavramı, “adeta tüm yazma deneyinde yer alan kavram örgüsünün en üst birimi” (Çotuksöken 1995: 106) olarak ortaya çıkar. Uygur "yazılmış yazılacak tüm kitaplar bir deyime bunalımlar kitabının önsözü durumunda" der (Uygur 2006: 9). Uygur'a göre "insan, özyaşamına, hangi açıdan yönelirse yalnızca o açıdan görünebileni görür” (Uygur 2006: 319). Bununla beraber bazı "anlam-bağlamları” vardır ki kişi hep onlarla birliktedir. Nermi Uygur için de bu “anlam-bağlamları”nın biri onun yaşadığı bunalımlardır. Onun bunalımları aynı zamanda onun hep içinde bulunduğu yaşam yönelişleri ya da onun yaşam yönelişleri bunalımlarıdır. Uygur'un bütün bir uğraşı bu yaşama bunalımlarıdır. Uygur yaşamı kendince “değerli, verimli ve güzel” kılmak ister. İşte onun yaşama sorunlarına verdiği bu değer bir yandan da felsefeyi kendi deyimiyle onun "asıl işi

\footnotetext{
${ }^{2}$ Çotuksöken, Uygur'un, Bunalımdan Yaşama Kültürü adlı kitabında onun "insana ilişkin antropontolojik (insan-ontolojisi, insan-varlıkbilgisi; kavram Çotuksöken'e aittir.) yaklaşımının iyice su yüzüne çıktığını” söyler. "Bunalım" onun gerçekliğe attığı ya da gerçekliğe gerdiği kavram ağının, çadırının, kasnağının, örtüsünün, peçesinin en canalıcı kavramıdır; çünkü "bunalım" dendiğinde, ona göre, insan dünyası aydınlanıverir." (Betül Çotuksöken, "Önsöz Yerine: Yazarlık Serüveninde 'Fenomenoloji'den ‘Çözümleyici Felsefe’ye Nermi Uygur”, Nermi Uygur, Bütün Eserleri-II, İstanbul: Yapı Kredi Yayınları, 2017, s. 6).
} 
gücü” yapmıştır. Böyle olunca da bunalım onun felsefi söyleminin ve bütün bir eserinin de dürtüsü olmuştur. Yapıtları bunun somut örnekleridir. Uygur yapıtlarında bunalımlardan bunalımlara koşuşturmuştur. Filozofun eserleri arasında konuyla ilgili örneklerden biri onun Edmund Husserl'de Başkasının Ben'i Sorunu (1998) adlı kitabının arka planındaki bunalımlardır. "Başkasının ben'i”" konusu filozof için onu hep bunaltan öznel bir sorun olmuş, başkalarıyla ilişkileri ve iletişim ona güçlükler çıkarmıştır.

Ne yapıp edip gidermek zorundaydım bu güçlükleri; dayanılır gibi değildi, sürekli acıtan bir yanı vardı insanlarla ilişkilerin. Güvenle sarılınca kırıklığa uğruyor, çekingen kalınca irkiliyordum. Aradabir dostluk güneşi açsa da, sakardı havalar. (Uygur 2006: 329).

Edmund Husserl'de Başkasının Ben'i Sorunu adlı eser, ben-sen ilişkilerinin getirdiği iletişim güçlüklerinin doğurduğu bunalımların neden olduğu yakınmaları dindirmek için filozofun yaşadığı düşünsel tedirginliklerin özümsenmesi sonucunda ortaya çıkmıştır. Fakat Uygur'un bunalımları bununla bitmez, hep başka bunalımlar vardır. Başka bunalımlar filozofa yine kendini, kendi bunalımlarını dile getirdiği başka denemeleri yazdırır. Bu kez Uygur'un yaşadığı bunalımın adı “dil çilesi”dir.

Dille sarhoştum, diyebilirim. Bastırdıkça bastırdı, bunalım . Yaşıyorsam, dilin o eşsiz hatırı için. İş-güç, ev-sokak, bir yandan da dil, hep birlikteydik onunla... Yaşıyordum, yazıyordum - neyi olacak, bunalımı, dili. Bunaldım, bunaldım, yazdım da yazdım (Uygur 2006: 3339).

Filozofun bunalım dürtüsüyle yazdığı bir başka denemesi olan Dilin Gücü böylesi bir bunalımın sonucunda doğmuştur. Uygur, Dilin Gücü (1997) için “Ucu-bucağ1 belirsiz bir bunalımda boğulmaktan kurtardı beni” der. Bu yapıtın dürtüsü olan bunalım “yaşamı dile çevirme” çabasıdır.

Filozofun felsefi söyleminde bunalımın dürtü olarak nasıl ortaya çıktığını örneklendirecek üçüncü yapıt onun Felsefenin Çağrısı (1995) adlı kitabıdır. Bu kez de Uygur'un bunalımında söz konusu olan onun “güvenli bilgi arayışı” çabalarıdır. Bunalımlarından hiçbiri bir diğerine benzemez; bu da yine bambaşka bir bunalımdır. 
Kıvır kıvır kıvranıyordum, -benzetmeli bir konuşma olsun diye öyle söylemiyorum, acılıydı gerçeğim. Yaşam da, söylem de, kuram da bulanık, belirsiz, sallantılı. Ayağımı basacak şöyle sağlam bir taban, gönlümün kafamın oh diyeceği rahat bir barınak gerekti bana... deli edecekti bu özlem beni (Uygur 2006: 335).

$\mathrm{Bu}$ çabayla Uygur, o sağlam bilgi ortamını bulmak adına dinin, sanatın, edebiyatın, matematiğin veya tarihin sağladığı bilgileri gözden geçirir. Hiçbirinde ulaşmak istediği sağlam bilgiyi elde edemeyeceğini görünce asıl uğraşı olan felsefede karar k1lar.

Kendine göre bir bilgi çağrısı vardı felsefenin, özel de olsa, böyle bir görev için çağrıydı felsefe, kendisine gerçekten yönelenleri böylesi bir yüce göreve çağırmaktaydı. Başlı başına bir bilgi etkinliği olarak soruşturup verimlendirmeye atıldım felsefeyi... (Uygur 2006: 336).

Felsefenin Çăgrısı filozofun yaşadığı işte bu bunalımların sonucunda doğar. Uygur bu yapıtında kendi bunalımlı kişiliği yönünden önemli olan "bilim saygısı", “dilin önemi” ve "felsefenin sağlam bir bilgi alanı olduğu” konularını sağlamlaştırdığına inanır.

Nermi Uygur bunalım ile deneme ilişkisi içinde, denemelerinde hep kendi bunalımlarını yazmıştır. Ortaya koyduğu sorunlar, dile getirdiği düşünceler hep onun bunalımlarla örülü yaşamının sözcüklere dökülmüş halidir. Doğal olarak Uygur'un bütün bir eserinin dürtüsü de bunalım olur; bunu da filozofun kendisi en güzel biçimde dile getirir:

....ne bunalım benden başka bir şey, ne deneme yaşamın dışında bir şey. Kendimi daha iyi anlayayım diye denemeleştirmişim bunalımlı yaşamı... Bunalımlar bitti mi, yaşam da bitmiştir (Uygur 2006: 354).

Bunalım kavramı, Nermi Uygur'un felsefi söyleminde dile geldiği haliyle felsefi danışmanlığın kullandığı anlamda sıkıntı/sorun kavramlarıyla önemli benzerliklere sahip olduğunu söylemek mümkün. Bunlar nelerdir. Bir sonraki bölümde bu benzer ve paralel yanlar somut olarak ele alınacak. 


\section{Bunalım Kavramının Nermi Uygur'un Felsefi Söylemindeki Haliyle Felsefi Danışmanlıkla ilişkilendirilmesi}

Uygur bunalım kelimesini çeşitli Avrupa dillerinde crisis veya krisis diye yazılan, Türkçe'ye de kriz olarak geçen sözcük anlamında kullanır (Uygur 2006: 208). Bunalım Uygur'un söyleminde, insanın her günkü yaşamında, örneğin, evde, çarşıda, pazarda, okulda, kırda, hastanede, bireysel ya da toplumsal ilişkilerinde hep birlikte olduğu sıkıntı/sorunlardır. Nermi Uygur'a göre bu sıkıntılar yaşamda insanın içine örülmüşş biçimde çok çeşitli görünümlerle ortaya çıkar. Değişik görünümleriyle "her günkü insan-toplum yaşamı" sıkıntılı ve bunalımlı bir yaşamdır. Bunalım "insan-toplum-tarihkültür evreninde" hem birey hem de toplum yaşamında hep olagelmiştir. İnsanın çocukluktan başlayarak bunalımla ilk karşılaştı̆̆ı yer ana-babanın koyduğu sınırlar, evet-hayırlar, yap-yapmalar, ana-baba ilişkilerindeki gerginlikler veya kardeşlerarası sorunlar, acılar, sallantılar veya yalpalanmaların yaşandığ evdir. Bunalımlar bireyin peşini bırakmaz. Ergenlik çağı bunalımlarla anılır çoğu kez.

Yetişkinlik veya olgunluk döneminde de bunalımlar son bulmaz sadece nitelik değiştirir; hatta çeşitlilik açısından zenginleşir. Bunalımlar daha sonra okulda, işyerinde ve bütün çeşitliliği ile yaşamın diğer görünümlerinde devam eder. Toplum yaşamında da bunalımlarla birlikteyizdir. Dönüşümlere yol açan devrimler veya benzeri uygulamalar, göç, iş, eğitim, sağlık, yönetim, hukuk, haklar gibi yaşama alanlarında görülen büyük-küçük, dar veya geniş kapsamlı rahatsızlıklar bunalımın toplum yaşamıyla olan vazgeçilmez bağını sergiler. Bunalımlar birey ve toplum yaşamının sadece pratik veya günübirlik alanıyla sınırlanamaz. Soyut ya da kuramsal olarak nitelendirilen matematik, fizik, mantık, felsefe veya resim, müzik, edebiyat, yontu, mimarlık gibi alanlar "bunalım dönemleri doğrultusunda, bunalımlar boyunca, bunalımdan bunalıma atlaya sıçraya" gelişirken bir yandan da günlük yaşamı da somut olarak etkilerler (Uygur 2006: 204-207).

Nermi Uygur'un bunalım sözcüğünü hangi anlamda kullandığıyla ilgili olarak yukarıda yapılan açıklamalardan anlaşılacağı gibi filozofa göre bunalım yaşamın her 
görünümünde ortaya çıkan gerçekliğin adıdır. ${ }^{3} \mathrm{Bu}$ noktada Uygur'un kullandı̆̆ 1 anlamda bunalım kavramı ile felsefi danışmanların kullandığı sıkıntı ve sorun kavramları arasında paralellikler hemen göze çarpmaktadır. Felsefi danışmanlar sıkınt1/sorunların tıpkı Uygur'un bunalım için ileri sürdügü gibi yaşamın her yanına yayıldığını, yaşamın kendisinin bir bölümüyle sorunlar yumağı olduğunu ileri sürerler (Lahav 1995, 1996b; Waller 2002; Tillmans 2005; Shibles 1998; Segal 1995). Hedeflerinde kişilerin günlük yaşamlarında karşılaştıkları ve altında onların dünyahayatgörüşleri veya alışılmış anlamalarının yattı̆̆ı sıkıntı/sorunlar vardır. Felsefi danışmanlar yaptıkları işin alanına giren sıkıntı/sorunların neler olabileceği hakkında böyle bir belirlemeyle, felsefi danışmanlığın kuramsal çerçevesini çizmeyi amaçlarken, bir yandan da danışanlarına çözmeleri için yardım ettikleri sorunları, psikolojinin alanına giren duygu durumlarıyla ilgili sorunlardan ayırmakla, yaptıkları işin kuramsal çerçevesi için çok önemli olan bir konunun altını çizmiş olurlar ki bu da felsefi danışmanlığın psikolojik danışmanlık ve psikoterapiden farklı bir danışmanlık türü olduğudur. Benzer biçimde Uygur'un felsefi söylemindeki bunalım sözcüğünün de psikolojik yüklerden mümkün olduğunca uzak olduğunu söylemek yanlış olmaz. Felsefi danışmanların sıkıntı/sorun sözcüklerini kullandıkları bağlam ile Uygur'un bunalım sözcüğünü kullandığı bağlam arasındaki bu belirgin benzerlik, kuramsal çerçevesinin oluşturulması hedeflenen felsefi danışmanlık için bu aşamada ileri sürülebilecek önemli

\footnotetext{
3 "Bunalım" kavramı için, Nermi Uygur'un felsefi söylemini en iyi anlayan, bilen ve bu konuda en yetkin isim Çotuksöken'e kulak kulak verelim: "İnsanın olduğu yerde ancak kriz ya da bunalım olur. Çünkü insan yapısı gereği bunalımlı bir öznedir ve bu saptamaya ek olarak bunalımları ya da krizleri fark eden, adını koyabilen, bunalımı başlatan, bunalıma çözüm yolu arayan bir varlıktır. Felsefe tarihinde öteden beri insan-bunalım birlikteliğine öncelik tanıyan düşünme gelenekleri varolmuştur. Augustinus, Nietzsche, Husserl özellikle bunalımın altını çizen filozoflardır. Nermi Uygur bu geleneklerin de çok iyi farkındadır; ancak bir bakıma toplumsal ya da doğrudan başkalarıyla ilişkilerinde değil de salt kendi varoluşunda, bedeniyle ilişkisinde bizzat deneyimlediği bunalımını, hastalıkla ilgili bunalımını sıçrama tahtası yaparak "bunalım" yaşantısına, "yaşanmış deneyim"ine (expérience vécue) yönelir ve bunalımlı olmayı, insan olmanın, insanı ve insan dünyasını anlamanın bir yapıtaşı durumuna getirir. Salt şimdide kalmayıp ileri ve geri gidişlerle, bellekle, bellekteki yaşantılarla varolan bilinçten dolayı bunalım varlığı olduğumuz açık. Ancak bunalım varlığı oluşumuzun da ardında olan en ortak insan fenomeninin "arada olmak" olduğunu ileri sürebiliriz tam da bu noktada. Nermi Uygur'un işaret etmediği bir yön olmakla birlikte, bunalımın da arkasında yer alan insansal durumun ve onunla bağlantısı içinde insansal duruşun "arada olmak"la birlikte gittiğini bir kez daha belirtebiliriz." (Betül Çotuksöken, "Önsöz Yerine: Yazarlık Serüveninde ‘Fenomenoloji'den 'Çözümleyici Felsefe'ye Nermi Uygur”, Nermi Uygur, Bütün Eserleri-II, İstanbul: Yap1 Kredi Yayınları, 2017, s. 7.)
} 
önemli noktaları içinde barındırır. Bunlardan birincisi Uygur'un bunalımların yaşamın kendisi olduğu, insanın kendisinin "yaşama bunalımı” olduğu, bunalımların bitmesinin yaşamın da biteceği anlamına geldiği, bunalımsız insanın yok olduğu, yok olunca da bir şey söylenemeyeceği ile ilgili belirlemeleridir. Bunalımın bu niteliği, bir felsefi danışmanlık uygulamasının hedef olarak aldığı önemli bir kavramla, 'bilgelik' kavramıyla kesişmektedir. Öncelikle Nermi Uygur'da bunalımların sürekliliğinin, felsefi danışmanların yaşamın kendisinin soru/sorunlar barındırdığı, dolayısıyla sorunların bitmeyeceği, bitmesini beklemenin de yanlış olduğu, onları çözmek yerine onlarla yaşamayı öğrenmenin daha doğru olacağıyla ilgili düşünceleriyle paralel olduğu daha önce belirtilmişti. Uygur'un bunalım kavramına, felsefi danışmanların da sıkıntı ya da sorun kavramlarına yüklediği bu özellik, felsefi danışmanların alternatif bir danışmanlık türü olarak çerçevesini çizmeye çalıştıkları alanları için ileri sürdükleri önemli bir yaklaşımı imler. Felsefi danışmanlar yaptıkları işi psikolojik danışmanlık ve psikoterapiden ayırırken, bu disiplinlerin ağırlıklı olarak kişinin içinde bulunduğu ana, şu anda yaşadığı sorunların çözümüne yöneldiğini, odak noktalarında şimdi yaşananlar olduğunu ileri sürerler (Raabe 2002b; Marinoff 2001,2007). Buna karşın felsefi danışmanlar için kişinin yalnızca 'şu anda' yaşadıkları değil, aynı zamanda 'gelecekte' yaşayacağı olası sorunlar, sıkıntılar da büyük önem taşımaktadır (Lahav 1994, 1995; Blass 1996b;). Sıkıntılar, sorunlar ve bunalımlar bitmeyip yaşamın kendisi olduğuna göre, kişiler gelecekte yaşayabilecekleri sorunlar için de hazır olmalıdırlar. $\mathrm{Bu}$ 'hazır olma’ hali felsefi danışmanların sıkça kullandığı ve onlar için çok önemli bir kavrama karşılık gelir; bu da 'bilgelik'tir. İnsan, bir kriz bilincine, bir bunalım bilincine sahipse o krizi görür, o bunalımı görür yakalar (Çotuksöken 2010: 90). Bilgelik, felsefi danışmanlar için yaşamı belirleyen zengin düşüncelere açık olmak, içinde bulunulan durumu anlamak, kabul etmek, yaşamın sorunlarına çözüm aramak yerine yaşamı daha iyi anlamak olarak tanımlanır (Lahav 1995, 1996a). Uygur'un bunalımlar karşısındaki tutumu, onlarla yaşaması, bunalımlarıyla boğuşması felsefi danışmanlığın bilgeliği bir ‘süreç' olarak gören anlayışıyla uyum içindedir. Uygur bu süreci denemelerinde yaşar.

Yaşamıma topluca bakınca, içlem kaplam yönünden, bunalımca gittikçe karışmış, durmadan daha karmaşık, daha geniş görünümlere bürünmüş yaşama oylumum. 
Denemelerime topluca bakınca, onlarda öyle: gittikçe daha yoğun, saçaklı, daha deli, daha akıllı bir oyluma bürünmüş denemeciliğim. Yaşamam, bunalımdan bunalıma seğirttikçe, daha bir kendim olmuşum denemelerimde (Uygur 2006: 353).

Yukarıdaki alıntıdan da anlaşılacağı gibi Uygur bunalımlarını denemelerinde yaşar, onları denemelerinde dile getirip yaşadıkça "daha bir kendi olur". Filozoftaki bu 'kendi oluş' sürecini felsefi danışmanlığın bilgelik süreci olarak değerlendirmek mümkündür. Bu süreç, Uygur'un anlatımıyla “ 'düpedüz akıl'dan vazgeçerek, daha yüksek bir akla ulaşmaktır (Uygur 2012: 27). Uygur denemelerinde varolan her şeye çok yönlü bir bakış açısı içinde yönelir, yeni yaşamında deneyimleriyle kendini, bu arada dünyayı sürekli olarak kurar (Çotuksöken 2012: 105).

Bunalım kavramının bir üst kavram olarak Uygur'un söyleminde yer aldığı haliyle felsefi danışmanlıkla ilişkilendirilebilecek bir diğer yönü iki ayrı görünümle felsefi danışmanlık yaklaşımlarında da görülür. Bunlardan ilki felsefi danışmanların danışmanlık sürecinde danışan ile felsefe yapmaları ve danışan özerkliğiyle ilgilidir.

Felsefi danışmanlığın bu özelliği aynı zamanda onu psikolojik danışmanlık ve psikoterapiden ayırır. Nermi Uygur'un denemeleri bir danışmanlık ortamı gibi görülebilir. Felsefi danışmanlık sürecinde danışman ve danışan nasıl birlikte felsefe yaparlar ve danışan da bu süreçte özerkdir. Uygur da denemelerinde bunalımlarını söze dökerken felsefe yapar ve haliyle de özerktir.

\footnotetext{
Denemeden denemeye geçerken, bunalımdan bunalıma atlamışım. Bunalımdan bunalıma zorlanırken, saydam, hafif, arı-duru yaşamlardayım. Bir bunalımı çözerken, ne göreyim, öbürüne dolanmışım; içinden çıkamayacağıma inandığım kesin bir açmazdayken, ne göreyim, çözülmüş bile çok şey (Uygur 2006: 353).
}

Uygur denemelerinde bunalımlarına çözümler getirir. Kendi kendinin felsefi danışmanıdır ve aynı zamanda özerk bir danışandır da. Uygur'un denemelerinde yaşama geçirdiği bu uygulama felsefi danışmanlık literatüründe 'self-trancendence', (Blass 1996a) 'kendini aşma' kavramıyla birlikte düşünülebilir. Bunalım kavramının Uygur'un söyleminde yer aldığı haliyle felsefi danışmanlıkla ilişkilendirilebilecek ikinci yönü iki ayrı görünümle ortaya çıkıyordu. Bunlardan birincisi yukarıda açıklandı. Bu görünümlerden diğeri ise, yine felsefi danışmanların yaptıkları işi felsefi yapan 
ölçütlerden biri olarak ileri sürdükleri, danışmanla danışanın birlikte felsefe yapması ve önceden belli hazır felsefi metinler veya reçeteleri kullanmama ilkesine ilişkindir ( Achenbach 1995; Schuster 1999; Lahav, 1995). Felsefi danışmanlar danışanların sorunlarına hazır çözümler sunma yerine, danışanın kendi çözümlerini üretecek yeni bir düşünce düzeyine, bakış açısına ulaşmalarını amaçlarlar. Felsefi danışmanların yaptıkları işi, 'tanı' ve o tanıya uygun hazır çözüm ve reçetelerle iş gördügüunü belirttikleri psikoterapiden ayırmak için vurguladıkları bu özellik, Uygur'un bunalım ve deneme ilişkisinde de söz konusudur. Uygur'un bunalımları çok çeşitlidir fakat her birinde bir diğerine benzemeyen bir biriciklik vardır. Uygur'un her bir bunalımında onu bunaltan ayrıdır dolayısıyla birden bire ortaya çıkan her bir bunalım kendi içinde ele alınır. Böyle olunca da bunalımlar için önceden düşünülmüş, hazırlanmış çözüm yolları kullanılamaz.

Nermi Uygur bunalımlarına felsefe içinde çözümler arar; yani felsefi danışmanların danışanla felsefe yapması gibi o da denemelerinde bir bakıma kendisiyle felsefe yapar.

Bunalım kavramının Uygur'un söyleminde yer aldığı haliyle felsefi danışmanlıkla ilişkilendirilebilecek bir başka özelliği ise, bunalımların “öznel” olmasıdır. Felsefi danışmanlara göre, felsefi danışmanlığı felsefi yapan bir diğer özellik de, ilgi alanlarına giren sıkıntı/sorunların genel soyut adları olsa da yaşananlar açısından kişiye özel olmasıdır. Felsefi danışmanlar belli belirtilere göre ulaşılan tanılara deneysel, önceden bilinen yöntemlerle yaklaşan psikolojinin tersine, biricik öznel sorunlar için, yine öznel çözümlere, felsefe yaparak ulaşmayı hedeflerler (Lahav 1995, 1996a). Nermi Uygur için de bunalımlar kişinin öznel dünyasını ilgilendirir, onun için de bunalım özneldir. Uygur bunalım yazarı, bunalımlar kitabının yazarıdır. Fakat her defasında kendini, kendi bunalımını yazar. O başkalarına "şunu yapın, bunalımlı zamanlarda şöyle davranın" (Uygur 2006: 290) demez çünkü herkes kendi bunalımını kendince yaşar. Bu özellik kendisini en belirgin şekilde Uygur'un bir bunalım tanımı yapma tavrında ortaya çıkar. Nermi Uygur, Bunalımdan Yaşama Kültürü adlı eserinde bir bunalım tanımı yapmanın bunalımın gerçekliği ile çelişeceğini ileri sürer. Herhangi bir varlık hakkında bir tanım 
yapmak onu "kendi içine kapalı, sınırları belirgin bir bütün", en önemlisi de onu insanın dışında bir nesne haline getirir (Uygur 2006: 321). Oysa bunalım, insana sonradan gelen, insanın dışında insan olmadan da var olan, insandan bağımsız "zaman-uzay içinde" yer alan bir nesne değildir. Aksine, "insana ilişkin", ona "özgü bir yaşantı", bir "gerçekliktir" (Uygur 2006: 211). Bunalım insana "yapışıktır"; insan ve bunalım arasında bir "varlıksal ilişki”, "içiçelik" vardır. "Bunalıma giren, bunalımdan çıkan, bunalıma düşen, bunalım atlatan, bunalımı önleyen, başından bunalım geçen, bunalıma yenilen, ondan korkmayan onunla savaşan” hep insandır. Her bunalım onu yaşayanın kendi bunalımıdır. Bunalımıyla hesaplaşan, bunalımıyla hesaplaşmasını kendince söze dökebildiği kadarıyla dile getiren kişinin bunalım hakkında söyledikleri ister istemez öznelliğin de izlerini taşır. Böyle olunca da, bir tanım arayışına girmek kavramı "daha baştan kaskatı kapamak" olur. Dolayısıyla filozofa göre "bunalımın herkesçe onaylanan bir tanımı yoktur." Söz konusu bunalım olunca doğası gereği birkaç cümle ile sınırlı olan bir tanımın çok da yeterli olmayan kesinliğiyle yetinmek yerine, filozofun bunalım üzerinde daha çok düşünmeye imkân sağlayan betimlemelerini gözden geçirmek bunalımı anlamak için çok daha etkilidir. Uygur'un bunalım ile ilişkili olarak kullandığı değişik betimlemeleri, benzetmeleri ve kavramları ele almadan önce bunalımın herkes için geçerli bir tanımının olmamasıyla ilgili özelliğinin felsefi danışmanlıkla olan ilişkisini belirleyelim. Bunalımın genel geçer ve nesnel bir tanımının yapılamaması, onu kolaylıkla açık-uçlu bir tartışmanın, felsefi danışmanların kullandığı kavramla felsefe yapma ediminin nesnesi yapar. Kendi öznelliği içinde bunalım hakkında dile gelenler kişisel olunca, felsefe yapmanın en önemli hedefi olan, yapılan felsefenin bireyselliği ilkesi hayata geçmiş olur. Bunun yanında, ortaya çıkan görüşlerin kişiye ait olması, genel geçer hazır reçeteler olmaması ve danışan özerkliğinin gerçekleşmesi gibi felsefi danışmanlığın kendini psikoterapiden ayırırken ileri sürdüğü özellikler de yine gerçekleşmiş olur.

Nermi Uygur'un bunalımı betimleme çabasında çok zengin bir dille karşılaşırız. Bunalımı betimlerken kullandığı bütün nitelemeler ve benzetmeler bunalım kavramını bize çeşitli yönleri ile duyumsatır. Uygur'un bunalımını anlatırken kullandığı bütün 
kavramlar, benzetmeler veya yaptığı betimlemeler bunları okuyan herkes için kendi bunalımlarını algılayıp anlamaları bakımından önemlidir. Örneğin, Uygur, bunalımı, yaşama dünyamızı ansızın ele geçiren bir karmaşa olarak niteler. Bunalımda insanın "bambaşka bir yerdedir" (Uygur 2006: 36). Niçin? Çünkü "gerçeklik tepetaklak" olmuştur. İnsan "kendi dişına sürülmüş", "benim dünyam bu artık” denen "bir yaşam kesitine" gözlerini açmıştır. Bunalım: birdenbire kendini hiçbir şey anlamadığın bir ortamda buluyorsun-bilmediğin, o güne dek işitmediğin bir dil konuşulan, dil denebilirse, konuşma denebilirse, kuşkusuz (...) Bunalımda: ne ben benim, ne de ben ben değilim: varım da yokum da. Bitiyor muyum, başlamadım; başlıyor muyum, bittim(...) Bunalımda: kendimden sonrayım, kendimden önceyim. Kendisiyle-arayerde-kalmışlık bunalım(...) Bunalım dedikleri: birdenbire esen çeşitli boraların ortasındasın-yağmur, kar, dolu, soğuk, sıcak, hepsi, birden üstüne çullanmış. Kutup yarası ile çöl yanığı dayanılmaz ayazlı soğukla boğucu bataklık 1slaklığı bir arada. Terlerken titriyor, donarken yanıyorsun (Uygur 2006: 371). Bunalım sırasında içinde bulunulan varlık durumu fillozofun diliyle düşüncelere şu sözcüklerle yansır: "dinamit kalıpları arasında dans ediyorsun; her an bir yerlerde bir çı̆̆ oluşmakta. Dünyayı insana kapar bunalım, küçültür insanı. İp üstündesin, cambazlık eğitimin yok, nota yok, çalgı yok, kendin bulup buluşturacaksın" (Uygur 2006: 373-374). Uygur'un bunalımı yaşayan bir kişi olarak, felsefi danışmanların kullandığı kavramlarla ifade edersek, kendi sıkıntı/sorununu ya da bunalımını bu denli açık, sağlıklı bir akıl yürütme ile açıklaması ve bunalımın onun dilinde kökü, kaynağı ve nedenleri ile bu şekilde dile gelmesi, bunalım kavramının Uygur'un söyleminde yer aldığı biçimiyle felsefi danışmanlığın, onu psikolojik danışmanlık/psikoterapiden ayıran ilkeleri ile paralellik göstermektedir. Schuster (1999), Marinoff (1995, 2012), Lahav (1995) ve Mujiskovic (1995) gibi felsefi danışmanlar felsefi danışmanlığın, sağlıklı düşünebilenler, akıl yürütebilenler, sorunları olduğunun farkında olup, bunları da sağlıklı bir biçimde açıklayabilen danışanları kapsadığını ve bu anlamda ortaya konabilen sıkıntılar için olduğunu ileri sürerler. Uygur'un kendi bunalımını dile getirirken kullandığı benzetmeler, nitelemeler ve akıl yürütmesinde görülen tutarlılık, onun bunalımını yaşarken sağlıklı düşünebildiğini göstermektedir. Ayrıca Uygur'un, felsefi 
danışmanların kavramıyla sıkıntısı, kendi kullandığı sözcükle bunalımı, kendi deyiş̧iyle "bunalımlı bir kavram" olmasına rağmen aynı derecede tutarlı çizgilerle ortaya konmuştur. Dolayısıyla Uygur'un bunalım kavramı ortaya konduğu şekliyle felsefi danışmanlar için kendilerini psikolojik danışmanlık/psikoterapiden ayırarak kuramsal bir çerçeve çizme uğraşında önemli bir kavramdır.

Bunalımı 'bunalım' yapan ilk özellik, bunalımın bir bilinç işi olmasıdır. Bir bunalım varlığı olan insan “bunalımlarla dokunmuş” dünyasında, bunalımlarla kol kola yaşarken çoğu zaman o günlük, alışılagelmiş yaşamı içinde, yaşamının "en iç dokusuna" kadar işlemiş, kendisine "yapışık" bunalımlarından habersizdir. İnsanın "Ben bir bunalım yaşıyorum" demesi onun bunalımının farkına varması, bunalımın bilincine erişmesi ile olur. Dolayısıyla, bunalımı 'bunalım' yapan özelliklerden biri, bunalımın, "bir bilinç işi, insana özgü bilincin işi”" olmasıdır (Uygur 2006: 216). Nermi Uygur'a göre bunalımı "bunalım” yapan "hiç şaşmayan görünümlerinden ikincisi: bunalımın birdenbire gelmesidir. Bunalım "geleceğim, geliyorum, gelirim diye önceden haber vermez" (Uygur 2006: 209).” Bu açıdan bunalım "beklenmedik”le anlamdaştır. Uygur'a göre insanların çoğu yaşamda sanki şaşırmaya hiç yer yokmuş gibi alıştıkları bir yaşam içinde, bunalımlar sanki "yazgımızın vazgeçilmez bir parçasıymış gibi" yuvarlanıp giderler. Sonra birden alışılmış düzenin bozulması ile bir "yalpalanma, bocalama" yaşanır. Yaşam artık o alıştığımız düzeninden çıkmış, hiç akılda olmayan bir yöne doğru gitmektedir. Her şey bunalımla iç içedir. Bunalım, işte böyle birdenbire gelir ama kendimizi hiç beklemediğimiz bir anda "bunalım evreninde" bulmamız, bir başka deyişle gözlerimizi birdenbire bambaşka bir ortamda açmamız, bunalımın anlık olduğunu, öncesinin ve sonrasının olmadığını da düşündürtmemelidir. Uygur, "şimdi ayık bir biçimde anlıyor gibiyim o güne seğirtiyormuşum meğer” demekle, bunalımın yılları kapsadığını da anlatmaktadır. Bunalım işte böyle birdenbire gelir ama bu birden bire gelen nedir? Bu birdenbire gelen, aynı zamanda da Nermi Uygur'a göre, bunalımı "bunalım” yapan "hiç şaşmayan görünümlerinden” üçüncüsü olan değişikliktir. Bu nasıl bir değişikliktir? Sorumuzun cevabını filozof şöyle verir: "boyutu, yoğunluğu, genel yapısı" tahmin edilemeyecek ölçüde "korkunç" -ki bu onun "beklenmedik, umulmadık" 
yanına işaret eder-, "bambaşka" bir değişikliktir. Peki, bunalımla değişen nedir? Her şey değişir. İnsanların içinde “yuvarlanıp gittikleri” düzen, “alışılmış işlerlik”, önce olan gider "değișen dengeyle" yok olur, biter ve yerini önce olana kıyasla bir "karmaşıklığa, kargaşaya" bırakır. Bu karmaşa içinde insan "allak bullak" olur, korkar, acı duyar. İnsan bunalım zamanlarında bir "darboğazda" sıkışır, sıkıntı duyar. Bu durum "temelden inen" beklenmedik, "ne zaman, nasıl biteceği belli olmayan", insan yaşamından "nice şeyleri götüren” "yıkım” ve güvensizlik yaratır. Uygur kendi bunalımı için "Ne oldu bana ?" diye sorar. O artık bunalımdan önceki insan değildir. Birden çok şeyin değiştiğini fark eder (Uygur 2006: 202-211). Filozofa göre bunalımı 'bunalım' yapan üç özellikten; bunalımın insana özgü bilincin işi ve bir değişiklik olması yine felsefi danışmanlığı psikoterapiden ayıran niteliklerle örtüşmesi açısından oldukça önemlidir. Felsefi danışmanlara göre bir sorunun felsefi danışmanlığın alanına girebilmesi için danışanın o sorunun farkında olması, bilincinde olması gerektiği daha önce belirtilmişti. Bu anlamda filozofun söylemindeki yeri ile bunalım kavramı yine bu yönüyle de bir yandan felsefi danışmanlıkta kullanılabilirken, diğer yandan da bu özelliği ile de felsefi danışmanlar için kuramsal alt yapılarını oluşturmaları adına çok önemli bir katkı sağlayabilir. Bunalımın bir değişiklik olmasının felsefi danışmanlığın bilgelik kavramı ile benzeşen yanları vardır.

Bilgelik kişinin yaşadığı sorun ya da bunalıma, bunalım sonrasında farklı açılardan, alıştığı düşünce ve algı kalıplarının dışında bakabilmesini sağlayan bir aşma ( Blass 1996a) durumudur. Filozof artık bunalımdan önceki insan değildir. Birden çok şeyin değiştiğini fark etmiştir.

\section{Sonuç}

Felsefi danışmanlığa bir uygulama alanı olarak, alanın temel çıkış noktasına sadık kalmak bakımından psikolojik yüklerden bağımsız yeni bir kavram kazandırma savını taşıyan bu çalışmada, hedef kavram önce çeşitli Avrupa dillerinde crisis veya krisis diye yazılan, Türkçe'ye de kriz olarak geçen sözcük anlamında "bunalım” olarak belirlendi. 
Daha sonraki aşamada felsefi danışmanlığın "felsefi”" olması açısından gerekli ölçütlere ${ }^{4}$ sahip bir kavram olarak "bunalımın" anlatılması gerekiyordu ki, Nermi Uygur'un bunalım söylemi bizim için tam da aranan kaynaktı. Bu amaçla bir önceki bölümde önce Nermi Uygur'un felsefi söyleminde bunalım sözcüğünün hangi bağlamda kullanıldığı ve kavramın filozofun söylemindeki yeri üzerinde duruldu. Uygur'un söyleminde bir “üst kavram”, yine bütün bir eserinin “dürtüsü” olan bunalım kavramının, onun söylemindeki bu haliyle felsefi danışmanlığın çalışma alanları için kullandıkları mevcut kavramlarıyla olan benzerlikleri ortaya kondu. Felsefi danışmanlar, danışanların her günkü yaşamlarında karşılaştıkları sıkıntı/sorunlarını hedef aldıklarını belirtir ve bu kavramların kapsamını açıklar. Felsefi danışmanlıkta sıkıntı ve sorun kavramları psikolojik yüklerden bağımsız, bireylerin alışılmış anlamaları, yanlış akıl yürütme, kötü mantık ile zaman içinde oluşan dünyahayatgörüşlerinin etkisiyle ortaya çıkan (danışanın kafasındaki bir mekanizmaya, nedensel bir ilişkiye bağlı olmayan, duygu durumlarının karışmadığı) sıradan insanın her günkü yaşamını ilgilendiren birçok ilişki ve eylemde bireylerin yaşayabileceği durumlardır. Dolayısıyla, felsefi danışmanların danışmanlık sürecinde ilgilendikleri sıkıntı/sorunların yanına bir diğer alan olarak ekleyebileceğimiz "bunalım”"ın da kavram olarak Uygur'un söyleminde ne anlama geldiği, tanımı ve nasıl bir kavram olduğunun açıklanması kavramın felsefi danışmanlıkla ilişkilendirilmesi işinde gerekliydi. Bu amaçla Uygur'a göre bunalımın ne olduğu ve nasıl bir kavram olduğu, Uygur'un kendi bunalımını anlattığı Bunalımdan Yaşama Kültürü adlı eserinde dile getirdikleri ile açıklandı.

Nermi Uygur'un bunalım kavramını hangi bağlamda kullandığı, kavramın onun söylemindeki yeri, bunalımın ne olduğu ve bunalımı 'bunalım' yapan özellikler ele alınarak, kavram bu özellikleriyle felsefi danışmanlıkla ilişkilendirildi. Uygur'un felsefi söyleminde "bunalım” kavramını felsefi danışmanlıkla ilişskilendirilmesi işinin en öne

\footnotetext{
${ }^{4}$ Felsefi kendini-soruşturmanın felsefi danışmanlığı diğer danışmanlık türlerinden farklı kılan ve e felsefi kendini-soruşturma olmak bakımından bu üç özelliğe sahip olması gerekir. Bunlar: felsefi kendinisoruşturma1) 'eleştirel'dir; 2) deneysel (empirik) değildir; 3)gizli olandan değil, açık olandan, bilinenden hareket eder. Bunalım kavramının Nermi Uygur'un felsefi söyleminde yer aldığı haliyle ve filozofun bunalımıyla hesaplaşma şekli bu üç özeeliği de taşımaktadır.
} 
çıkan yönü hiç şüphesiz merkezinde insanı bulunduran bir felsefe yapma biçimi olan felsefi danışmanlık için Uygur'un felsefi söyleminde insan-bunalım bağıdır. Nermi Uygur'un insan bunalımlarına ilişkin söylemi ve felsefi danışmanların çalışma alanları olarak belirlediği danışan sıkıntı/sorunların, gerek Uygur'un kendi bunalımını sözcüklere nasıl döktüğü, gerekse de felsefi danışmanların literatürde kendi çalışma alanları olan sıkıntı/sorunları nasıl tanımladıkları üzerinden yapılan ilişkilendirme sonucunda ortaya çıkan birebir benzerlikler neticesinde bunalım kavramının felsefi danışmanlıkta psikolojik yüklerden uzak bir kavram olarak kullanılabileceği görülmüştür. 


\section{KAYNAKÇA}

ACHENBACH, Gerd (1984). Philosophische Praxis, Köln: Jürgen Dinter.

ACHENBACH, Gerd (1995). Philosophy, philosophical practice, and psychotherapy, R. Lahav \& M.d.V. Tillmans (Eds.), Essays on philosophical counseling içinde (s. 61-75). New York: University Press of America.

AMIR, Lydia. B (2004). "Three questionable assumptions of philosophical counseling", International Journal of Philosophical Practice, 2(1), 9-18.

BLASS, Rachel (1996a). "Philosophical counselling and Zen: On the possibility of Self transcendence." Journal of Chinese Philosophy, Say1 23, 277-90.

BLASS, Rachel (1996b). "The 'Person' in Philosophical Counselling vs. Psychotherapy and The Possibility of Interchange between the Fields", Journal of Applied Philosophy, 1, 13, 3.

ÇOTUKSÖKEN, Betül (1995). Nermi Uygur'un Felsefe Dünyasindan Kesitler. İstanbul: Kabalcı Yayınevi.

ÇOTUKSÖKEN, Betül (2001). Bunalımdan Yaşama Kültürü̈. Felsefeyi Anlamak Felsefe ile Anlamak. İstanbul: İnkılap Kitapevi.

ÇOTUKSÖKEN, Betül (2010a). "Krizden Bir Yaşama Kültürü Çıkar mı?", Yeni, 1, 84-118. İstanbul: Kırmızı Yayınları.

ÇOTUKSÖKEN, Betül (2012). "Nermi Uygur's Philosophical Discourse". Journal of Turkish Studies, 37, 103-118.

ERTÜRK, İsmail (2010). “Krizden Bir Yaşama Kültürü Çıkar mı?”, Yeni, 1, 84118 İstanbul: Kırmızı Yayınları.

JOPLING, David (1996). "Philosophical counselling, truth and selfinterpretation", Journal of Applied Philosophy, 13, 297-310.

JONGSMA, Ida (1995). Philosophical counseling in Holland: History and open issues. In R. Lahav \& M. de Venza Tillmanns (Eds.), Essays on philosophical counseling içinde (ss.25-34), Lanham, MD: University Press of America.

IŞIN, Ertürk (2010). “Krizden Bir Yaşama Kültürü Çıkar mı?” Yeni, 1,84-118 İstanbul: Kırmızı Yayınları.

LAHAV, Ran (1994). Philosophical personal investigation in philosophical counseling. Read at the First International Conferena on Philosophical Counseling, The University of British Columbia, July, 1994.

LAHAV, Ran (1995). A Conceptual Framework for Philosophical Counseling: Worldview Interpretation. R. Lahav \& M.d.V. Tillmans (Eds.), Essays on philosophical counseling içinde (s. 3-24). New York: University Press of America. 
LAHAV, Ran (1996a). "What is philosophical in philosophical counselling?", Journal of Applied Philosophy, 13, 259-78.

LAHAV, Ran (1996b). "Philosophical Counseling and Taoism: Wisdom and Lived Philosophical Understanding”, Journal for Chinese Philosophy, 23, 259-276.

LAHAV, Ran (2001). "Philosophical Counselling as a Quest for Wisdom", Practical Philosophy, 4, 1, 6-18.

MARINOFF, Lou (1995). On the emergence of ethical counseling: Considerations and two case studies. R. Lahav \& M. de Venza Tillmanns (Eds.), Essays on philosophical Counseling içinde (ss.171-192). Lanham, MD: University Press of America.

MARINOFF, Lou (2001). Philosophical Practice. San Diego, CA: Academic Press.

MARINNOFF, Lou (2007). Felsefe Hayatınızı Nasıl Değiştirir. Çeviren: İstem Erdener. İstanbul: Pegasus Yayınları.

MARTIN, Mike (2001). "Ethics as Therapy: Philosophical Counseling and Psychological Health”, International Journal of Philosophical Practice, 1,1.

MEHURON, Kate (2009). "Supervision and Case Notes in Philosophical Counselling Practice" Philosophical Practice: Journal of the American Philosophical Practice Association, 4(2) 467-474.

MIJUSKOVIC, Ben (1995). Some reflections on philosophical counseling and Psychotherapy. R. Lahav \& M.d.V. Tillmans (Eds.), Essays on philosophical counseling içinde (ss.101-120). New York: University Press of America.

MORSTEIN, Petra.V (1987). Breath Life into Philosophy, Professor Urges. Calgary Herald, 11 September, F14

PRINS-BAKKER, Anette (1995). Philosophy in marriage counseling. R. Lahav \& M.d.V. (Ed.), Essays on philosophical counseling içinde (ss.135-151). New York: University Press of America.

RAABE, Peter. B (2000). Philosophical Counselling: Theory and Practice. Westport, CT: Praeger.

RAABE, Peter B (2002a). Issues in Philosophical Counselling. Westport, CT: Praeger Publishers.

RAABE, Peter B (2002b). "The Life Examined in Philosophical Counseling" Practical Philosophy, 5(1).

SCHEFCZYK, Michael (1995). Philosophical counselling as a critical examination of life-directing conceptions. R. Lahav and M. Tillmanns (eds) Essays on Philosophical Counseling içinde (ss.75-84) Lanham: University Press of America. 
SEGAL, Steven (1995). Meaning crisis: Philosophical counseling and psychotherapy. R. Lahav \& M.d.V. Tillmans (Eds.), Essays on philosophical Counseling içinde (ss.101-120). New York: University Press of America.

SHIBLES, Warren (1998). "Philosophical counseling, philosophical education and emotion", International Journal of Applied Psychology, 12, 19-36.

SCHUSTER C. Shomit (1999). Philosophy Practice: An Alternative to Counseling and Psychotherapy. London: Praeger.

TILLMANNS, M.Da Venza (2005). "Philosophical Counseling: Understanding the Unique Self and Other through Dialogue", International Journal of Philosophical Practice, 2 (4).

TUEDIO, James (1998). Philosophical Counseling As A Window On The Abstract Realities Of Everyday Life. California State University, Stanislaus Philosophical Counseling as a Window. Yayınları.

TURAN, Güven (2011). Nermi Uygur Denemeci, İstanbul: Yap1 Kredi

UYGUR, Nermi (1995). Felsefenin Çă̆rısı, İstanbul:YKY.

UYGUR, Nermi (1997). Dilin Gücü, İstanbul:YKY. YKY.

UYGUR, Nermi (1998). Edmund Husserl'de Başkasının Ben'i Sorunu. İstanbul:

UYGUR, Nermi (2006). Bunalımdan Yaşama Kültürü. İstanbul:YKY.

UYGUR, Nermi (2012). Yaşama Felsefesi. İstanbul:YKY.

VEENING, Eite (1994). "Metalugue in philosophical counseling", Read at the First International Conference on Philosophical Counseling, the University of British Columbia. July, 1994.

WALLER, Sara (2002). "How Does Philosophical Counseling Work? Judgment and Interpretation", International Journal of Philosophical Practice,1(2). 